\title{
A Footnote on the Need for Local Subject Cataloging
}

\author{
Dr. Merritt is professor of librarianship, \\ University of California.
}

$\mathrm{T}$

HE RESEARCH which resulted in the publication of The Use of the Subject Catalog in the University of California Library $^{1}$ made possible the gathering of a small additional amount of data, the reporting of which did not seem relevant to the main subject catalog inquiry. The hypothesis on which those data are based, however, is interesting and relevant to the problem of subject cataloging in libraries generally, and is presented here for that reason. In order to provide the necesary background for the reader who may not have the basic document at hand, the following paragraphs are quoted from the summary:

It was revealed that the use of books progressively diminishes as they become older, and that somewhat more recent books are chosen from the subject catalog than are located in the author catalog. When a convenient age limit of twenty years is set, it is found that 49.6 per cent of all loans through the subject catalog are not more than twenty years old. It was shown further that $7 \mathrm{I}$ per cent of books currently being cataloged are not more than twenty years old. When these two facts are related, it is possible to anticipate a reduction of 29 per cent in the amount of subject cataloging by postulating a policy of providing subject display only for books less than twenty-one years old. Such a policy would, over a period of years, result in a reduction in subject coverage of only 15 per cent based on books loaned through use of the subject catalog. That is, users of the

${ }^{1}$ Merritt, LeRoy Charles. The Use of the Subject Catalog in the University of California Library. (University of California Publications in Librarianship, v. I, No. 1.) Berkeley, University of California Press, r951. library would borrow 15 per cent fewer books through use of the subject catalog than they now do.

The major discrepancy between books cataloged and books loaned was discovered among foreign language material. Although 50 per cent of all titles currently being cataloged are in foreign languages, only 6.2 per cent of all books loaned through the subject catalog were written in foreign languages. Thus the subject-cataloging load could be reduced by 50 per cent while reducing the efficiency of the subject catalog by only 6.2 per cent, on a purely quantitative basis.

To this 50 per cent reduction in subjectcataloging load on foreign material it is possible to add a 29 per cent reduction of the remaining half of books in English if subject cataloging is eliminated for books more than twenty years old, resulting in a total reduction in subject-cataloging load of 64.5 per cent. Concomitant reduction in the amount of subject display affected by use of the subject catalog would be 21.2 per cent. Phrased differently, and in rounder numbers, if subject cataloging were to be dropped for all foreign books and for all English books more than twenty years old, subject-cataloging load would be reduced immediately by 65 per cent. The efficiency of the subject catalog in terms of books circulated with its help would progressively decline to a level not lower than 80 per cent of its present effectiveness.

The Harper Method. In modern university libraries the process of subject cataloging is fully integrated with the process of classification. Since the same thought processes are involved in assigning a subject heading as are involved in choosing a proper classification number, the two functions are desirably performed at the same time. It follows then that substantial savings cannot be made by eliminating only 
one of the two processes; classification must be modified as well if projected savings in subject cataloging are to be significant and important.

A solution has been offered by Professor Lawrence A. Harper of the University of California Department of History which is at once intriguing and challenging. If it could be placed into effect, a similar though differently distributed reduction in subject cataloging would result in a similar reduction in subject catalog efficiency of only twenty per cent.

Professor Harper suggests the possibility that full and complete subject catalog display is necessary only for those books for which Library of Congress cards are available, that most of the books approached through the subject catalog are those books which are acquired and cataloged by the Library of Congress. Proceeding on this assumption, he suggests ( $\mathrm{I}$ ) that full subject display be given only to those books for which LC cards are available, (2) that all other books be given descriptive cataloging only and be shelved in order of receipt without classification, and (3) that as LC cards become available for books handled as in (2), the books be withdrawn from their special location and be given full subject cataloging and classification.

In connection with the subject catalog inquiry, it was possible to test this suggestion by a special analysis of a limited subject-catalog-derived sample which contained call cards representing 1784 charges. By checking each of these books with the official shelf-list, it was found that 1211 , or 68 per cent, had been cataloged on $\mathrm{Li}$ brary of Congress cards at the time the books were acquired. Since it sometimes occurs that LC cards are printed after the University of California Library has done its own cataloging, the remaining 573 cards produced locally were checked with the Library of Congress Depository Cata- $\log$, which is a complete catalog of all cards ever printed by the Library of Congress. LC cards were found there for an additional 225 books, making a total of I 436 books for which LC cards were available at the time the books were used. Thus, had the Harper method been followed in its entirety during the last 50 years, the subject catalog would be 80 per cent as effective in locating desired material by subject as it is now. These data are recapitulated in Table $\mathrm{I}$.

\section{Table I}

Incidence of Library of Congress Cards in the Cataloging of ${ }_{1784}$ Books Loaned Through the Subject Catalog

Number Per Cent

Original Cataloging on LC

Cards

I2 I I

67.9

Subsequent Publication of

LC Cards

225

12.6

Total LC Cards Available at Time Books Were Used 1436

80.5

Total Loans Derived from

Subject Catalog

${ }_{17} 84$

100.0

If the library were to adopt the Harper method, it would no longer be necessary to do any original subject cataloging or classification; all could be done with the assistance of the subject headings and classification numbers already printed on the Library of Congress cards. For the last three years Library of Congress cards have been available for approximately fifty per cent of the titles cataloged by the University of California Library. Reduction in subject cataloging and classification load would thus amount to at least this fifty per cent, in terms of titles cataloged, and would in fact amount to more than that because the reduction would occur for the more difficult fifty per cent for which LC cards are not available. Accurate figures of this

(Continued on page 24I) 
Germaniae historica. Marburg/Lahn, Simons Verlag, 195I. 2 pts. in I vol.

Index to New Zealand Periodicals and Current National Bibliography of New Zealand: Books and Pamphlets Published in 1950, ed. by A. L. Olsson. Wellington, N. Z., Library Association, 195I-

Contents 1950: Sec.1, p. I-124, Index (to 58 periodicals); Sec.2, p. 125-142, Current national bibliography.

International Political Science Abstracts. Documentation politique internatiunale. Oxford, I95I- v.I-

Jansonius, Herman. Groot nederlandsengels woordenboek voor studie en practijk. Leiden, Nederlandsche uitgeversmaatschappij N. U., 1950Deel I, A-Moesson.

Lambrino, Scarlat. Bibliographie de l'antiquité classique, I896-1914. Paris, Société d'Édition "Les Belles Lettres," 195I- I. pte. Auteurs et textes. (Collection de bibliographie classique.)

Larousse mensuel illustré. La seconde guerre mondiale. . numéro special du Larousse mensuel de 1939 à 1947 (no. 400).... Paris, Larousse, 1952. 522p.

Le Livre bleu: recueil biografhique donnant les noms, addresses, profession, titres et qualités des personnalités qui se sont fait un nom en belgique par leurs oeuvres ou leur activité dans le domaine des arts, des sciences et des lettres, de la politique et de l'administration, de l'industrie et du commerce. Bruxelles, Larcier, 1950. 532p. il.

Oxford Dictionary of Nursery Rhymes, edited by Iona and Peter Opie. Oxford, Clarendon Press, 195I (reprinted with corrections, 1952). $467 \mathrm{p}$. il.

Palumbo, Pier Fausto. Bibliografia storica internazionale, 1940-1947; con una introduzione sullo stato degli studi storici durante e dopo la seconda guerra mondiale. Roma, Le Edizioni del Lavoro, 1950. 241p.

Preobrazhenskiī, Aleksander Grigor'evich. Etymological Dictionary of the Russian Language. New York, Columbia University
Press, 195I. 674p., 416p., I44p. (Columbia Slavic studies.)

Robert, Paul. Dictionnaire alphabétique et analogique de la langue française; les mots et les associations d'idées. . . . Paris, Société du Nouveau Littré, Presses Universitaires de France, 195I- Fasc. I-3. A-Astre.

Sanders, Chauncey. An Introduction to Research in English Literary History; with a chapter on research in folklore by Stith Thompson. New York, Macmillan, 1952. 423p.

United Nations Educational, Scientific and Cultural Organization. Répertoire des bibliothèques de france. Paris, Bibliothèque nationale, 1950-5i. 3v.

U.S. Copyright Office. Motion Pictures, 1912-1939. [Washington] Govt. Print. Office, 1951. 1256p. (Its Catalog of copyright entries. Cumulative series)

Weber, Shirley Howard. Voyages and Travels in the Near East Made during the $X I X$ Century; Being Part of a Larger Catalogue of Works on Geography, Cartography, Voyages and Travels, in the Gennadius Library of Athens. Princeton, N. J., American School of Classical Studies at Athens, 1952. 252p. (Catalogues of the Gennadius Library, I)

Webster's New World Dictionary of the American Language. Encyclopedic edition. [General editors] Joseph H. Friend and David B. Guralnik; etymological editor Harold E. Whitehall. Cleveland, World Publishing Co., 1951. 2v.

Who's Who in the United Nations. Ist ed. ed. by C. E. Burckel. Yonkers-on-Hudson, Burckel, 1951il.

Willaert, Léopold. Bibliotheca janseniana belgica. Répertoire des imprimés concernant les controverses théologiques en relation avec le jansénisme dans les pays-bas catholiques et le pays de liège au xvii et xviii ${ }^{\circ}$ siècles. Paris, Vrin, 1949-51. 3v. (Bibliothèque de la faculté de philosophie et lettres de namur. Fasc. 4, 5, 12)

\section{Local Subject Cataloging (Continued from page 233)}

saving are not at hand, but it is not unreasonable to estimate the total saving at the same 65 per cent found to obtain were subject cataloging to be eliminated for for- eign books and English books more than twenty years old. This would certainly be true when it is considered that classification is eliminated as well. 